\title{
Study of the Influence of Anionic Composition of Salts on Synthesis of Zinc Orthostannate by the Sol-Gel Method
}

\author{
Valeriy Anisimov ${ }^{1, *}$, Aleksey Saprykin ${ }^{1}$, Irina Artemkina ${ }^{1}$, and Nikolay Makarov ${ }^{1}$ \\ ${ }^{1}$ Dmitry Mendeleev University of Chemical Technology of Russia (Moscow, Russia)
}

\begin{abstract}
The effect of anionic composition of zinc salts upon interaction with tin (IV) chloride on preparation of zinc orthostannate by the sol-gel method was studied. It was determined that the minimum temperature for the synthesis of zinc orthostannate was $800{ }^{\circ} \mathrm{C}$. It was revealed that when zinc chloride was used, tetraaminezinc chloride was formed, which decomposed during firing. When zinc acetate or zinc sulfate was used, the synthesis of zinc orthostannate was not fully completed up to $1100^{\circ} \mathrm{C}$.
\end{abstract}

\section{Introduction}

Depending on the ratio of elements in $\mathrm{ZnO}-\mathrm{SnO}_{2}$ system, there are two compounds: zinc metastannate $\mathrm{ZnSnO}_{3}$ with a perovskite structure and zinc orthostannate $\mathrm{Zn}_{2} \mathrm{SnO}_{4}$ with a reverse spinel structure [1-3]. Zinc orthostanate, which is an n-type semiconductor, due to its low toxicity, high electron mobility, resistance to high temperatures and thermodynamic stability is used in gas analyzers, photocatalysts, photovoltaic devices, transparent electrodes and lithium batteries [4-6]. Recently, zinc orthostannate has been used as a buffer layer in solar cells due to its high optical transparency and significant resistivity, which makes it a promising material for new highly efficient solar cells $[7,8]$.

Zinc orthostannate is obtained by various methods: solid-phase synthesis from oxides [9], electrochemically [10], by co-precipitation of salts [11, 12]. The sol-gel method is promising for the synthesis of ultradispersed zinc orthostannate powder that is active for sintering. A feature of the sol-gel method is the possibility of obtaining fragments of oxides of complex composition in a gel, which minimizes diffusion obstacles during synthesis, shortens the time of its implementation, and promotes a uniform distribution of components at the molecular level $[13,14]$. In addition, the use of the sol-gel method makes it possible to reduce production costs by reducing the synthesis temperature, as well as to obtain materials with desired properties, such as phase composition, structure, specific surface area, etc.

Modification of the sol-gel technology based on the synthesis of a gel of a high molecular weight polymer and distribution of a homogeneous true solution of one or several components in it, followed by drying and calcination, enables one to obtain monodisperse powders of metal oxides of simple or complex composition $[15,16]$.

\footnotetext{
* Corresponding author: vvanisimov@muctr.ru
} 
The study is an observation of the effect of anionic composition of zinc salts on the synthesis of zinc orthostannate by the sol-gel method when interacting with tin (IV) chloride.

\section{Experimental part}

For the study, we used the following salts: $\mathrm{SnCl}_{4} \cdot 5 \mathrm{H}_{2} \mathrm{O}, \mathrm{ZnCl}_{2}, \mathrm{Zn}\left(\mathrm{NO}_{3}\right)_{2} \cdot 6 \mathrm{H}_{2} \mathrm{O}$, $\mathrm{Zn}\left(\mathrm{CH}_{3} \mathrm{COO}\right)_{2} \cdot 2 \mathrm{H}_{2} \mathrm{O}, \mathrm{ZnSO}_{4} \cdot 7 \mathrm{H}_{2} \mathrm{O}$, as well as $\mathrm{NH}_{4} \mathrm{OH}$ and $\left(\mathrm{NH}_{4}\right)_{2} \mathrm{CO}_{3}$ as precipitants. The taken substances had a level of purity 'Purified' and higher.

For preparation of gels of a mixture of tin (IV) and zinc salts $\mathrm{SnCl}_{4}+\mathrm{Zn}\left(\mathrm{NO}_{3}\right)_{2} ; \mathrm{SnCl}_{4}$ $\left.+\mathrm{Zn}\left(\mathrm{CH}_{3} \mathrm{COO}\right)_{2} ; \mathrm{SnCl}_{4}+\mathrm{ZnSO}_{4}\right)$, taken in the stoichiometric ratio $\mathrm{ZnO}: \mathrm{SnO}_{2}=2: 1$, taking into account losses on ignition, were dissolved in a previously prepared $8 \%$ * solution of polyvinyl alcohol upon heating $\left(40-50{ }^{\circ} \mathrm{C}\right)$ and stirring. To obtain hydroxides, an aqueous solution of ammonia or a saturated aqueous solution of ammonium carbonate was poured into the resulting mixture to a value of $\mathrm{pH}=7-8$, while precipitation and intense gas evolution were observed. The resulting gels were kept for $24 \mathrm{~h}$ at room temperature to complete gelation process, after which they were dried to constant weight using microwave radiation (at a power of $800 \mathrm{~W}$ ). Xerogels were fired in a furnace in the temperature range from 700 to $1100{ }^{\circ} \mathrm{C}$ with a holding time of $2 \mathrm{~h}$. The phase composition of the samples was studied using a DRON-3M X-ray unit. Radiation - $\mathrm{CuK} \alpha$, detector scintillation counter. To identify crystalline phases, the Joint Committee on Powoler Diffaction Standarts international card index was used.

\section{Discussion of the results}

Based on the literature data [9], the synthesis of zinc orthostannate from tin (IV) and zinc oxides occurs at a temperature of $1300{ }^{\circ} \mathrm{C}$. When using chemical methods, for example, coprecipitation of salts, due to formation of small defective particles, the synthesis temperature of zinc orthostannate decreases to $950{ }^{\circ} \mathrm{C}$ [12]. To study the possibility of obtaining orthostannate by the sol-gel method, the temperature range of $800-1100{ }^{\circ} \mathrm{C}$ was chosen, which was explained by the expectation of a decrease in the temperature of the beginning of synthesis due to the formation of ultradispersed particles active during sintering. Since the use of alkalis to obtain hydroxides from initial salts in the case of the sol-gel technology will be unjustified due to the further need to purify the powder from alkali metal cations and their negative impact on the electro-physical properties of the resulting gels and final powders, an aqueous solution of ammonia was initially chosen as a precipitant, which is associated with its availability, as well as the ease of removal of byproducts formed during hydrolysis of salts with the formation of $\alpha$-stannic acid and zinc hydroxide (Schemes 1-4).

$$
\begin{gathered}
\mathrm{SnCl}_{4}+4 \mathrm{NH}_{4} \mathrm{OH}+(\mathrm{n}-1) \mathrm{H}_{2} \mathrm{O} \rightarrow \mathrm{H}_{2} \mathrm{SnO}_{3} \cdot \mathrm{n} \mathrm{H}_{2} \mathrm{O} \downarrow+4 \mathrm{NH}_{4} \mathrm{Cl} \\
\mathrm{Zn}\left(\mathrm{NO}_{3}\right)_{2}+2 \mathrm{NH}_{4} \mathrm{OH} \rightarrow \mathrm{Zn}(\mathrm{OH})_{2} \downarrow+2 \mathrm{NH}_{4} \mathrm{NO}_{3} \\
\quad \mathrm{NH}_{4} \mathrm{Cl} \rightarrow \mathrm{NH}_{3} \uparrow+\mathrm{HCl} \uparrow \\
\mathrm{NH}_{4} \mathrm{NO}_{3} \rightarrow \mathrm{N}_{2} \mathrm{O} \uparrow+2 \mathrm{H}_{2} \mathrm{O} \uparrow
\end{gathered}
$$

During subsequent firing, $\alpha$-stannic acid decomposes to tin (IV) oxide, and zinc hydroxide to zinc oxide, after which zinc orthostannate is formed (Schemes 5-7). The onset of formation of zinc orthostannate is observed at $1000{ }^{\circ} \mathrm{C}$, which follows from the results of XRF (Fig. 1). 


$$
\begin{aligned}
& \mathrm{H}_{2} \mathrm{SnO}_{3} \cdot \mathrm{n} \mathrm{H}_{2} \mathrm{O} \rightarrow \mathrm{SnO}_{2}+(\mathrm{n}+1) \mathrm{H}_{2} \mathrm{O} \\
& \mathrm{Zn}(\mathrm{OH})_{2} \rightarrow \mathrm{ZnO}+\mathrm{H}_{2} \mathrm{O} \\
& 2 \mathrm{ZnO}+\mathrm{SnO}_{2} \rightarrow \mathrm{Zn}_{2} \mathrm{SnO}_{4}
\end{aligned}
$$

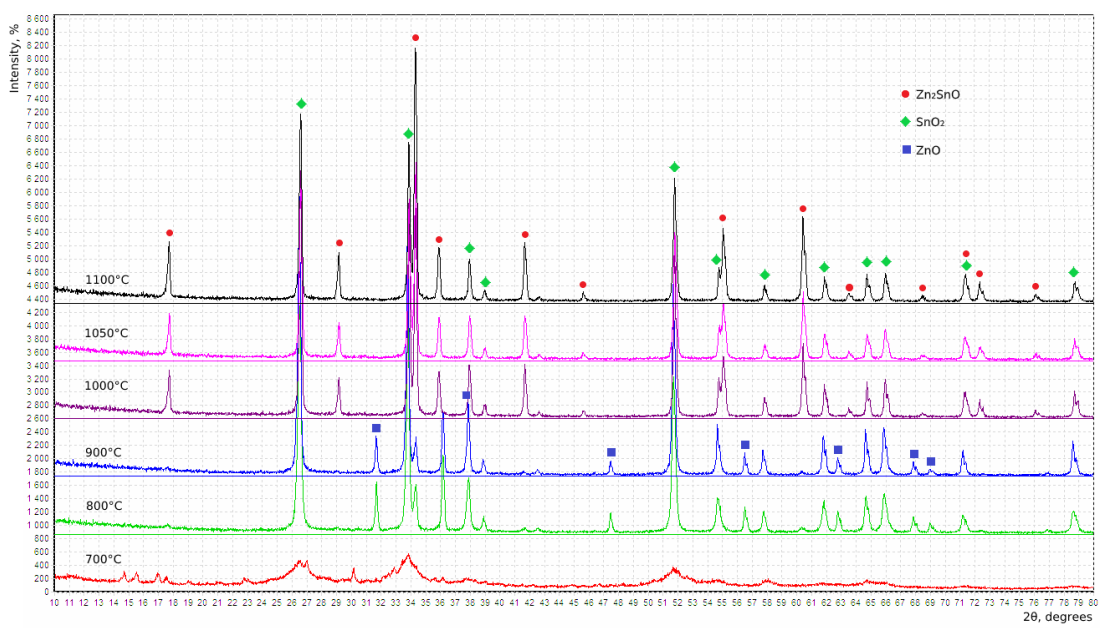

Fig. 1. XRF results for powders obtained using tin (IV) chloride, zinc nitrate, and aqueous ammonia as a precipitant

When tin (IV) chloride and zinc chloride are used as starting components, the target product is not formed during precipitation with an aqueous solution of ammonia. Obviously, this is due to peculiarities of the chemistry of zinc, which is an amphoteric metal and, when interacting with ammonia, forms a hydroxide (Scheme 8), which subsequently dissolves in an excess of ammonia with the formation of tetraminezinc chloride (Scheme 9). The resulting complex salt decomposes during firing to zinc chloride $\left(\mathrm{Tb}=732^{\circ} \mathrm{C}\right)$ and ammonia (Scheme 10).

$$
\begin{aligned}
& \mathrm{ZnCl}_{2}+2 \mathrm{NH}_{4} \mathrm{OH} \rightarrow \mathrm{Zn}(\mathrm{OH})_{2} \downarrow+2 \mathrm{NH}_{4} \mathrm{Cl} \\
& \mathrm{Zn}(\mathrm{OH})_{2}+2 \mathrm{NH}_{4} \mathrm{OH}+2 \mathrm{NH}_{4} \mathrm{Cl} \rightarrow\left[\mathrm{Zn}\left(\mathrm{NH}_{3}\right)_{4}\right] \mathrm{Cl}_{2}+4 \mathrm{H}_{2} \mathrm{O} \\
& {\left[\mathrm{Zn}\left(\mathrm{NH}_{3}\right)_{4}\right] \mathrm{Cl}_{2} \rightarrow \mathrm{ZnCl}_{2} \uparrow+4 \mathrm{NH}_{3} \uparrow}
\end{aligned}
$$

Thus, the further use of ammonia as a precipitant for tin (IV) and zinc chlorides is impractical.

Subsequent studies were carried out using a saturated aqueous solution of ammonium carbonate, which underwent hydrolysis to form ammonium bicarbonate (Scheme 11). During thermolysis, ammonium bicarbonate completely decomposes with formation of ammonia, carbon dioxide and water, which eliminates the influence of foreign ions on gelation process and the properties of powders. The reactions of ammonium bicarbonate with tin (IV) chloride, zinc nitrate, zinc chloride, zinc acetate and zinc sulfate are shown in Schemes 12-16, respectively.

$$
\begin{gathered}
\left(\mathrm{NH}_{4}\right)_{2} \mathrm{CO}_{3}+\mathrm{H}_{2} \mathrm{O} \leftrightarrow \mathrm{NH}_{4} \mathrm{HCO}_{3}+\mathrm{NH}_{4} \mathrm{OH} \\
\mathrm{SnCl}_{4}+4 \mathrm{NH}_{4} \mathrm{HCO}_{3}+(\mathrm{n}-1) \mathrm{H}_{2} \mathrm{O} \rightarrow \mathrm{H}_{2} \mathrm{SnO}_{3} \cdot \mathrm{n} \mathrm{H}_{2} \mathrm{O} \downarrow+4 \mathrm{NH}_{4} \mathrm{Cl}+4 \mathrm{CO}_{2} \uparrow \\
\mathrm{Zn}\left(\mathrm{NO}_{3}\right)_{2}+2 \mathrm{NH}_{4} \mathrm{HCO}_{3} \rightarrow \mathrm{Zn}(\mathrm{OH})_{2} \downarrow+2 \mathrm{NH}_{4} \mathrm{NO}_{3}+2 \mathrm{CO}_{2} \uparrow \\
\mathrm{ZnCl}_{2}+2 \mathrm{NH}_{4} \mathrm{HCO}_{3} \rightarrow \mathrm{Zn}(\mathrm{OH})_{2} \downarrow+2 \mathrm{NH}_{4} \mathrm{Cl}+2 \mathrm{CO}_{2} \uparrow \\
\mathrm{Zn}\left(\mathrm{CH}_{3} \mathrm{COO}\right)_{2}+2 \mathrm{NH}_{4} \mathrm{HCO}_{3} \rightarrow \mathrm{Zn}(\mathrm{OH})_{2} \downarrow+2 \mathrm{CH}_{3} \mathrm{COONH}_{4}+2 \mathrm{CO}_{2} \uparrow \\
\mathrm{ZnSO}_{4}+2 \mathrm{NH}_{4} \mathrm{HCO}_{3} \rightarrow \mathrm{Zn}(\mathrm{OH})_{2} \downarrow+\left(\mathrm{NH}_{4}\right)_{2} \mathrm{SO}_{4}+2 \mathrm{CO}_{2} \uparrow
\end{gathered}
$$


As with the use of ammonia as a precipitant of tin (IV) chloride and zinc nitrate, formation of zinc orthostannate when using ammonium bicarbonate is observed at temperatures of $1000{ }^{\circ} \mathrm{C}$ and above (Fig. 2).

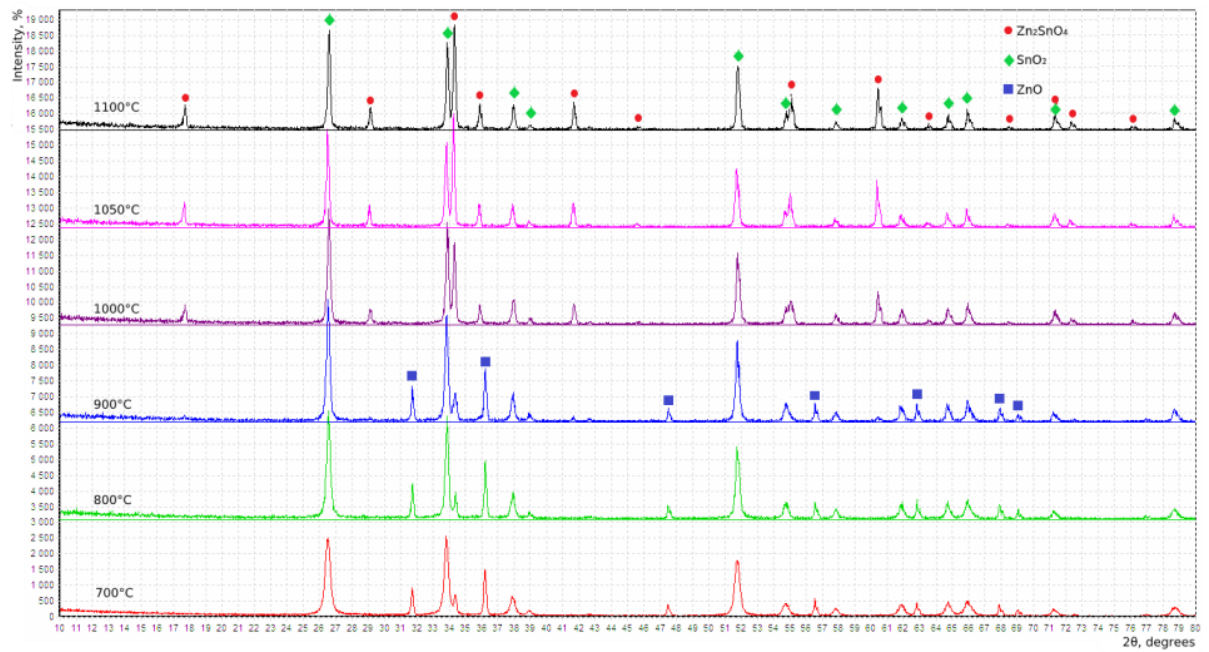

Fig. 2. XRF results for powders obtained using tin (IV) chloride, zinc nitrate, and an aqueous solution of ammonium bicarbonate as a precipitant

The yield of zinc orthostannate when using ammonium bicarbonate is lower than when using ammonia, which is associated with a higher $\mathrm{pH}$ value of the latter and, therefore, a deeper course of precipitation reactions.

The use of ammonium bicarbonate for the precipitation of tin (IV) chloride and zinc chloride made it possible to obtain zinc orthostannate, in contrast to experiments with ammonia (Fig. 3).

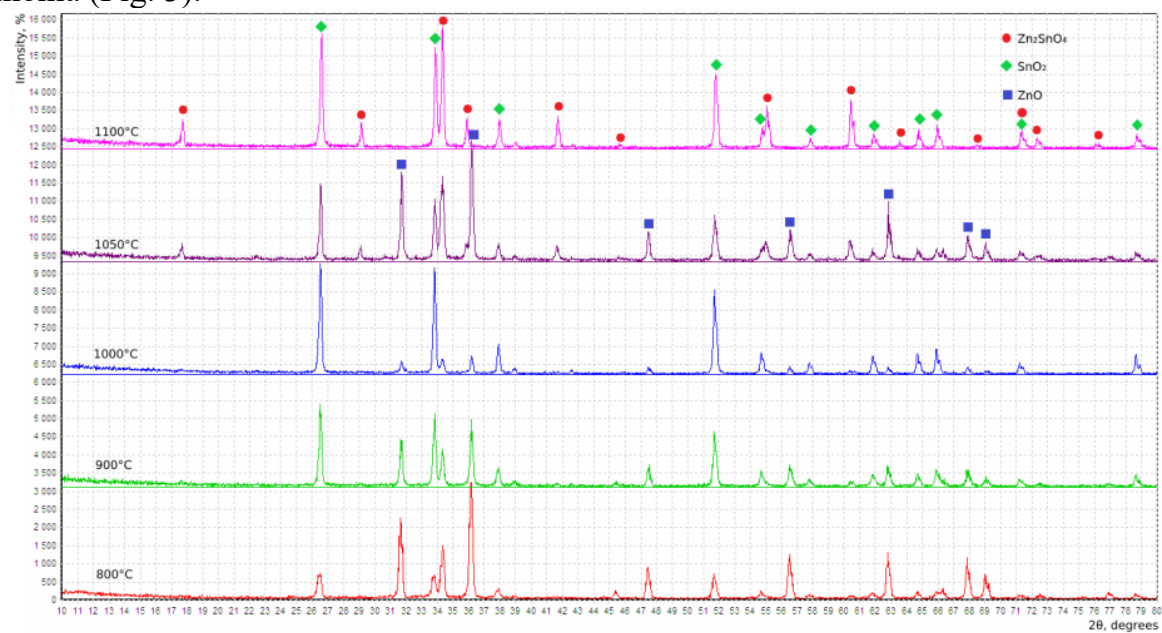

Fig. 3. XRF results for powders obtained using tin (IV) chloride, zinc chloride, and an aqueous solution of ammonium bicarbonate as a precipitant

It follows from the radiographs that formation of the zinc orthostannate phase is completed at $1100{ }^{\circ} \mathrm{C}$. The yield of the target zinc orthostannate was $20 \%$. Apparently, this is due to the fact that when zinc chloride interacts with ammonium bicarbonate, zinc 
hydroxide is formed, which, in an excess of the precipitant, does not completely transform into a complex compound (Schemes 14,17), but remains in the system, and decomposes to zinc oxide, which, in turn, reacts with tin (IV) oxide to form zinc orthostannate.

$$
\mathrm{Zn}(\mathrm{OH})_{2}+2 \mathrm{NH}_{4} \mathrm{HCO}_{3}+2 \mathrm{NH}_{4} \mathrm{Cl} \rightarrow\left[\mathrm{Zn}\left(\mathrm{NH}_{3}\right)_{4}\right] \mathrm{Cl}_{2}+2 \mathrm{CO}_{2} \uparrow+4 \mathrm{H}_{2} \mathrm{O}
$$

Further studies were carried out using tin (IV) chloride and zinc acetate. The obtained X-ray diffraction patterns (Fig. 4) show that the phase of zinc orthostannate is formed already at $800{ }^{\circ} \mathrm{C}$, but the synthesis does not proceed to the end: up to a temperature of $1100{ }^{\circ} \mathrm{C}$, zinc and tin oxides are present.

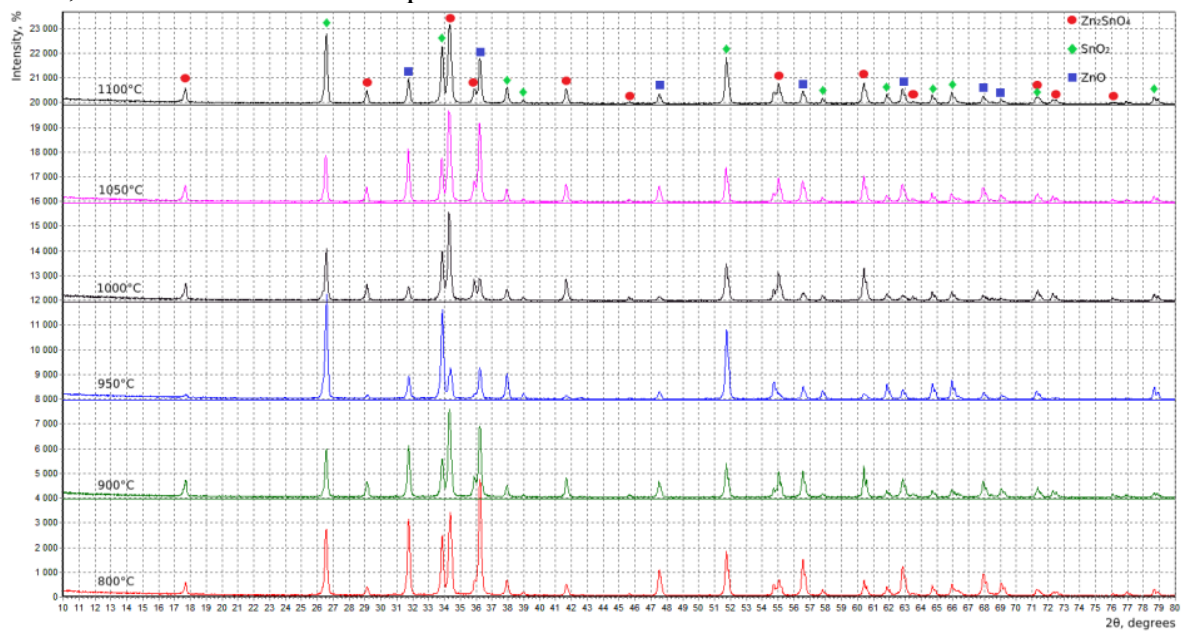

Fig. 4. XRF results for powders obtained using tin (IV) chloride, zinc acetate, and an aqueous solution of ammonium bicarbonate as a precipitant

As in the case of zinc acetate, when zinc sulfate is used as the initial salt upon interaction with tin (IV) chloride, the formation of zinc orthostannate phase is observed at $800{ }^{\circ} \mathrm{C}$, but the reaction does not proceed completely, which follows from the XRF results, in which at all temperatures tin and zinc oxides are present (Fig. 5).

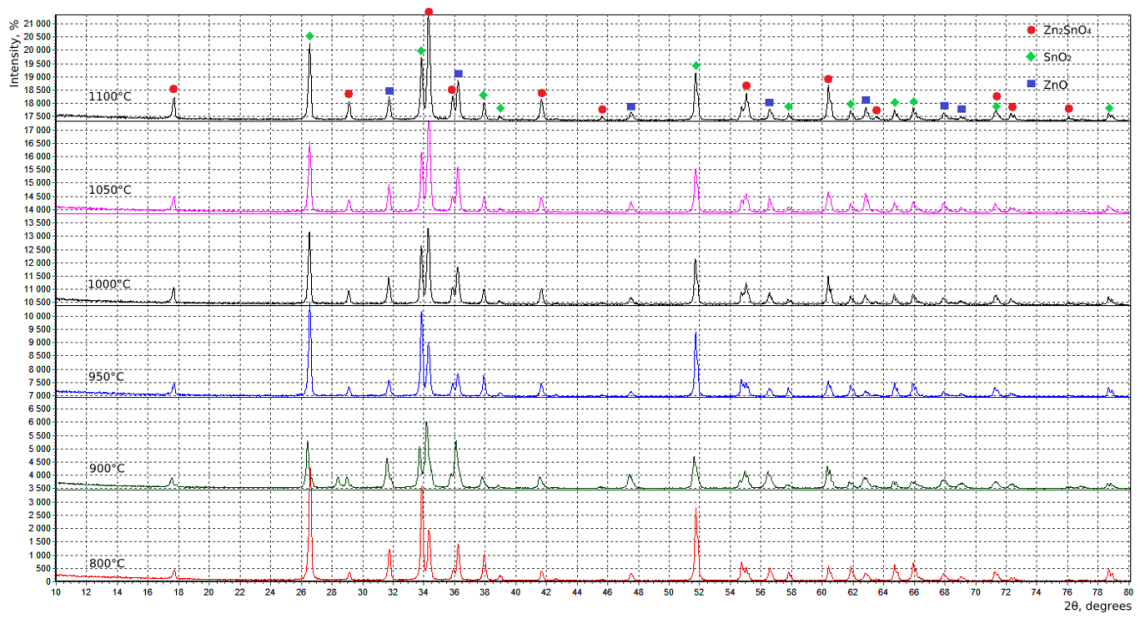

Fig. 5. XRF results for powders obtained using tin (IV) chloride, zinc sulfate, and an aqueous solution of ammonium bicarbonate as a precipitant 
It is obvious that for the reaction of zinc orthostannate formation when using tin (IV) chloride, as well as zinc acetate or sulfate, it is necessary to select the heat treatment mode and use a longer holding time at the studied synthesis temperatures.

In the synthesis of zinc orthostannate from tin (IV) chloride and zinc nitrate in the temperature range $1000-1100{ }^{\circ} \mathrm{C}$, in addition to the target product, tin (IV) oxide is present, while zinc oxide is consumed completely (Fig. 1,2). This may be due to the fact that zinc metastannate preliminarily formed in the system at $750{ }^{\circ} \mathrm{C}$ transforms into zinc orthostannate with the formation of tin (IV) oxide (Scheme 18) [17].

$$
2 \mathrm{ZnSnO}_{3} \rightarrow \mathrm{Zn}_{2} \mathrm{SnO}_{4}+\mathrm{SnO}_{2}
$$

On the other hand, the literature describes the possibility of influence of the difference in the diffusion coefficients of cations on the stoichiometry of complex oxides. During the synthesis of complex oxides from a mixture of oxides taken in a stoichiometric ratio and the vacancy diffusion mechanism, due to the difference in the diffusion coefficients of the metals forming the oxides, a solid oxide solution containing a more slowly diffusing cation is initially formed in the complex oxide. The second cation forms a separate or enriched phase with it. The appearance of a solid solution (deviation from stoichiometry) causes formation of oxygen and cation vacancies, the diffusion rate of which in the complex oxide is higher [18]. Consequently, to obtain a complex oxide with a composition close to stoichiometric, it is necessary to select a heat treatment mode, which is the subject of separate studies.

\section{Conclusions}

Thus, as a result of the study, it was found that:

1. The use of tin (IV) chloride and zinc chloride as starting components for obtaining zinc orthostannate by the sol-gel method is impractical;

2. When tin (IV) chloride interacts with zinc acetate or zinc sulfate, the phase of zinc orthostannate is formed at relatively lower temperatures, but the reaction does not proceed completely up to $1100{ }^{\circ} \mathrm{C}$, and therefore their use is irrational;

3. When using tin (IV) chloride and zinc nitrate, the target zinc orthostanate is formed at $1000{ }^{\circ} \mathrm{C}$, which is confirmed by XRF data;

4. It is preferable to use an aqueous solution of ammonium bicarbonate as a precipitant.

\section{References}

1. Sivapunniyam A., Wiromrat N., Myint M. T. Z., Dutta J. High-performance liquefied petroleum gas sensing based on nanostructures of zinc oxide and zinc stannate // Sensors and Actuators B: Chemical. 2011. V. 157. N 1. P. 232-239.

2. Rama S., Avadhesh Kumar Y., Chandkiram G. Synthesis and humidity sensing investigations of nanostructured $\mathrm{ZnSnO}_{3} / /$ Journal of sensor technology. 2011. V. 1 . P. 116-124.

3. Lu F., Liu Q. Structure and optical band gap of inverse spinel $\mathrm{Zn}_{2} \mathrm{SnO}_{4}$ epitaxial films // Journal of Low Temperature Physics. 2020. V. 200. P. 142-151. 
4. Belousov S.A., Nosov A.A., Rembeza S.I., Kosheleva N.N. Synthesis and electrophysical properties of gas-sensitive films $\mathrm{Zn}_{2} \mathrm{SnO}_{4}$ // Izvestiya SFedU. Technical science. 2016. No. 10. P. 19-27.

5. Dou J., Li X., Li Y., Che Y., Wei M. Fabrication of $\mathrm{Zn}_{2} \mathrm{SnO}_{4}$ microspheres with controllable shell numbers for highly efficient dye-sensitized solar cells // Solar Energy. 2019. V. 181. P. 424-429.

6. Chen Y.C., Shen Y.R. Growth and dielectric characterizations of zinc stannate thin films deposited by RF magnetron sputtering // Integrated Ferroelectrics. 2018. V. 192. N. 1. P. $80-87$.

7. Tai M., Zhao X., Shen H., Guo Y., Zhang M., Zhou Y., Li X., Yao Z., Yin X., Han J. Lin $\mathrm{H}$. Ultrathin $\mathrm{Zn}_{2} \mathrm{SnO}_{4}$ (ZTO) passivated $\mathrm{ZnO}$ nanocone arrays for efficient and stable perovskite solar cells // Chemical Engineering Journal. 2019. V. 361. P. 60-66.

8. Kim D. W., Shin S. S., Cho I. S., Lee S., Kim D. H., Lee C. W., Jung H. S., Hong K. S. Synthesis and photovoltaic property of fine and uniform $\mathrm{Zn}_{2} \mathrm{SnO}_{4}$ nanoparticles // Nanoscale. 2012. V. 4. N. 2. P. 557-562.

9. Nikolić M. V., Ivetić T., Paraskevopoulos K. M., Zorbas K. T., Blagojević V., Vasiljević-Radović D. Far infrared reflection spectroscopy of $\mathrm{Zn}_{2} \mathrm{SnO}_{4}$ ceramics obtained by sintering mechanically activated $\mathrm{ZnO}-\mathrm{SnO}_{2}$ powder mixtures // Journal of the European Ceramic Society. 2007. Vol. 27. N. 13-15. P. 3727-3730.

10. Govindappa C. K., Venkatarangaiah V. T., Abd Hamid S. B. Electrochemical generation of cubic shaped nano $\mathrm{Zn}_{2} \mathrm{SnO}_{4}$ photocatalysts // Nano-micro Letters. 2013. V. 5. N. 2. P. 101-110.

11. Peiteado M., Iglesias Y., De Frutos J., Fernández J. F., Caballero A. C. Preparation of $\mathrm{ZnO}-\mathrm{SnO}_{2}$ ceramic materials by a coprecipitation method // Boletin de la Sociedad Espanola de Ceramica y Vidrio. 2006. V. 45. N. 3. P.158-162.

12. Sidorak A.V., Shubin A.A., Ivanov V.V., Nikolaeva N.S. Synthesis of $\mathrm{Zn}_{2} \mathrm{SnO}_{4}$ powders by heat treatment of coprecipitated compounds // Journal of Siberian Federal University. Chemistry. 2011. V. 4. No. 3. P. 285-293.

13. Abdel Gawad Safaa Ramadan Mahmoud. Cordierite ceramics from powders obtained by the sol-gel method: dis. ... Cand. Tech. Sciences: M.: RKhTU named after D.I. Mendeleev. 2006. 160 p.

14. Faykov P.P. Synthesis and sintering of powders in $\mathrm{MgO}-\mathrm{Al}_{2} \mathrm{O}_{3}$ system obtained by the sol-gel method: dis. ... Cand. Tech. Sciences. M.: RKhTU named after D.I. Mendeleev. 2007.163 p.

15. Vlasov A.S., Krainova L.I. Use of sol-gel processes in ceramics technology. Tr. MHTI named after D.I. Mendeleev. 1988. No. 153, P. 110-115.

16. Andrianov N.T. Sol-gel processing in the technology of oxide materials // Glass and Ceramics. 2003. N. 10. P. 17-22.

17. Bora T., Al-Hinai, M. H., Al-Hinai A. T. Dutta J. Phase transformation of metastable $\mathrm{ZnSnO}_{3}$ upon thermal decomposition by in-situ temperature-dependent raman spectroscopy // Journal of the American Ceramic Society. 2015. V. 98. P. 4044-4049.

18. Belyakov A. V. The effect of difference in diffusion coefficients of cations on deviation from stoichiometry in complex oxides // Glass and Ceramics. 1997. N. 10. P. 18-20. 